\title{
Grundtvig i økumenisk perspektiv
}

\section{Af Peter Lodberg}

I de senere år er der udkommet en række skrifter, der har bragt yderligere dimensioner til vores opfattelse af N.F.S. Grundtvigs teologiske forfatterskab ved at forstå ham som en økumenisk teologisk tænker ${ }^{1}$. Vi ved i dag, at Grundtvig i forhold til sin samtid var overraskende åben over for andre kirkesamfund og teologiske traditioner. Han formåede at indoptage deres teologiske synspunkter og gøre dem til genstand for en konstruktiv kritik til gavn for sine egne hovedpositioner. I den forstand var Grundtvig en teolog, der varetog katoliciteten i den kristne teologi med sit arbejde inden for rammerne af den universelle kirke med inspiration fra både den latinske kristenhed og den østlige ortodoksi på sin tids vilkår.

Samtidig må det understreges, at Grundtvig var en stridbar økumenisk teolog. Han forsøgte ikke at harmonisere de forskellige konfessionelle positioner, som om sandheden altid ligger mellem to yderpunkter. Han var hverken ireniker eller ufrugtbar kontroversteolog, men søgte at formulere sine egne teologiske positioner, som om han skulle aflægge regnskab for den kristne tro i ansvarlighed over for den måde, hvorpå den kristne kirke gennem tiderne har forvaltet den apostolske forkyndelse ${ }^{2}$.

Der er i dag god anledning til at overveje, hvorvidt Grundtvigs systematisk-teologiske positioner kan bidrage med værdifulde indsigter til den $\varnothing$ kumeniske læresamtale mellem kirkesamfundene. Inden for den seneste tid har den luthersk-anglikanske læresamtale om embedsteologi i forbindelse med Porvoo Fælleserklæringen og den luthersk-katolske dialog om retfærdiggørelseslæren været genstand for debat i Danmark. I begge tilfælde har Grundtvigs synspunkter været fremført som udelukkende negative kommentarer til, hvordan folkekirkens biskopper skal forholde sig til en evt. tiltrædelse af de foreslåede erklæringer.

Det hænger uden tvivl sammen med, at eftertiden har tolket Grundtvigs teologi som en enestående dansk teologi, hvor dens unikke nationale karakter for den danske folkekirke er blevet fremhævet på bekostning af andre grundlæggende teologiske indsigter og synspunkter i Grundtvigs teologiske forfatterskab. Det fremgår især af de forord, som genudgiverne af Grundtvigs skrifter har forsynet disse med. Det hedder således i forordet til Kirkeligt Samfunds genudgivel- 
se af Grundtvigs Kirkens Gienmale i 1925: „Som det første fremkomne Udtryk for Grundtvigs Menighedssyn og som Bannermærke for dansk Kristendoms Kamp for Fædrenetroen udsendes »Kirkens Genmæle« nu i Mindeaaret paa ny i nøjagtig samme Skikkelse som første Udgave fra 1825 « $^{3}$. Men er Grundtvig så éntydig en unik dansk teolog, at »den nationale tolkning « kan stå alene, sådan som Hans Krings og Anders Nørgaards forord lader forstå? Det er nødvendigt at brede spørgsmålet ud, så det kan forsøges besvaret ud fra sin rette historiske kontekst. Historikeren Ove Korsgaard har i den sammenhæng gjort opmærksom på, at med den franske revolution gik den gamle forbindelse mellem stat og kirke i stykker, og at det nationale fællesskab derfor kunne rykke ind på religionens plads som samfundets ideologiske grundlag. Det nye og vigtige tema $\mathrm{i}$ forbindelse med modernitetens fødsel bliver derfor i Danmark if. Korsgaard forholdet mellem danskhed og kristendom ${ }^{4}$. If. Korsgaard arbejdede Grundtvig sig på skoleområdet frem mod en klar sondring mellem det nationale og det kristelige i modsætning til flertallet af højskolefolket som fx Kold, Trier og Schrøder. Derimod er Korsgaard mere i tvivl, når det gælder Grundtvigs teologiske og kirkelige forståelse af forholdet mellem nationalitet og kristendom. Problemet med Grundtvig er if. Korsgaard, at Grundtvig både skelner skarpt mellem kristendom og nationalitet, Helligånd og folkeånd, kirke og skole, samtidig med at han fastholder en forbindelse. Der er således tale om en vekselvirkning hos Grundtvig mellem folkeåndens universalhistorie og Helligåndens frelseshistorie, hvor sidstnævnte if. Korsgaard har prioritet. Korsgaard konkluderer:

»Selv om Grundtvigs tanker om forholdet mellem kristendom og nationalitet, mellem helligånd og folkeånd, har været genstand for talrige afhandlinger, så synes sagen endnu ikke fuldt belyst. Det kan enten skyldes, at Grundtvig aldrig selv nåede til fuld klarhed over problemstillingen, eller også at han i virkeligheden kom frem til en så radikal anden forståelse af kristendommen end den lutherske, at det har været svært at forstå ham, selv for hans nærmeste: grundtvigianerne ${ }^{5}$.«

Korsgaard er selv inde på, at årstallet 1848 spiller en meget vigtig rolle for forståelsen af Grundtvigs skoletanker, fordi Treårskrigen betød, at begreber som danskhed, folkelighed, livs-oplysning kom til 
at indtage en ny og meget central placering i Grundtvigs tankeverden $^{6}$. Desværre fors $\varnothing$ ger Korsgaard ikke at efterspore disse begivenheders - endsige krigen i 1864 - betydning for Grundtvigs kirkelige anskuelse og dermed for forholdet mellem nationalitet og kristendom, men bliver stående ved sit åbne spørgsmål og sin undren.

Men i forlængelse af Korsgaards understregning af, at Grundtvigs arbejde betyder en ny gennemtænkning af forholdet mellem kirke og stat - nu blot på det nationale fællesskabs præmisser - falder det helt naturligt i det følgende at analysere det, som Grundtvig selv kalder sit »Begreb om Kirken« med særlig vægt på at belyse det nationales placering i dette kirkesyn. Var Grundtvigs kirkesyn så nationalt, som Korsgaard fremhæver? Det er ikke sikkert, hvis man tager udgangspunkt $\mathrm{i}$ hans systematisk teologiske overvejelser om kirken, således som disse kommer frem i Grundtvigs opgør med H.N. Clausen i "Kirkens Gienmaele" og i tiden herefter.

Der er ingen tvivl om, at Grundtvig har betragtet »Kirkens Gienmaele" som et afgørende bidrag i sit forfatterskab til beskrivelsen af den kristne kirkes teologiske selvforståelse. Dels har opgøret med H.N. Clausen været så dramatisk, at det har præget Grundtvig i lang tid - ikke mindst på grund af de personlige omkostninger med bøde og afgang som præst, dels var opgøret teologisk set så fundamentalt for Grundtvigs teologi, at han gentagne gange vender tilbage til "Kirkens Gienmaele" og dets teologiske problemstillinger, som han ikke kan slippe. Det gælder ikke blot i skrifterne »Skal den Lutherske Reformation virkelig fortsættes? « fra 1831 og genudgivet i uforandret form af Grundtvig i 1863, »Den danske Statskirke Upartisk Betragtet « fra 1834, men også i artiklerne fra Nordisk Tidsskrift for christelig Theologi 1840-42 under overskriften »Kirkelige Oplysninger Isar for Lutherske Christne". Det interessante i denne sammenhæng er, at Grundtvigs udgangspunkt er det universelle og økumeniske perspektiv ved kirkeforståelsen og ikke et dansk, endsige et konfessionelt luthersk perspektiv ${ }^{7}$.

H.N. Clausen og Grundtvig var principielt uenige om, hvad der hører til henholdsvis katolicismens og protestantismens væsen, og om disse to udgaver af Vestkirkens kristendom i deres teologiske grundstruktur er uforenelige. H.N. Clausens hovedsynspunkt i hans store bog fra 1825 »Catholicismens og Protestantismens Kirkeforfatning, Lare og Ritus" var at fastholde en principiel teologisk og kirkelig praktisk uforenelighed mellem henholdsvis katolicismens og pro- 
testantismens væsen. Protestantisme springer if. H.N. Clausen på grund af sin natur kirkehistorien over og vender umiddelbart tilbage til kristendommens fødsel ${ }^{8}$. Traditionen har, således som den bevidnes af kirkens historie gennem tiderne, ingen teologisk betydning som bevidnelse af den kristne tros indhold. Kirkehistorien er kun en mørk, vildsom labyrint af modstridende beretninger og fortolkninger. H.N. Clausen $\emptyset$ nsker at vende tilbage til Kristus som eneste Herre og Mester, og til dette formål kan kirken selv og dens historie kun stå $\mathbf{i}$ vejen. Princippet om Kristus alene får to konsekvenser for H.N. Clausen. For det første opfattes Skriften som den eneste ubetingede troeskilde, og for det andet betyder det, at ingen kirke af historiske grunde har ret til at kalde sig den sande kirke. Dermed har H.N. Clausen fået etableret den afgørende væsensmæssige modsætning mellem katolicisme og protestantisme. Protestantismen modsætter sig »det empiriske Begreb, den historiske Construction af Kirken, som stridende mod den religiøse Characteer, og kan ikke andet end erklære Catholicismens Princip for uchristeligt, under hvilken Form det end udvikler sig, som Tro paa Pave eller paa Concilier, efterdi det løssiger sig fra Christus, og i Tiden nødvendigvis medfører Forfalskning af Evangeliets Lære. ${ }^{9}$ H.N. Clausen anfører, at denne negative afgrænsning i forhold til katolicismen har sit positive protestantiske modstykke i protestantismens skelnen mellem den usynlige og den synlige kirke. Med baggrund i Confessio Augustana art. VII bestemmer H.N. Clausen den sande kirke som det samfund, »i hvilket Evangeliet rettelig læres, og Sacramenterne rettelig bestyres. ${ }^{10}$ Denne kirke lader sig if. H.N. Clausen ikke opvise på jorden. Den er et ideal, som det menneskelige samfund stræber efter. Det er netop denne stræben mod det højere, den indadvendte filosofiske karakter, forbundet med den klare adskillelse af det usynlige og det synlige, det guddommelige og det menneskelige, som er karakteristisk for protestantismen og adskiller den fra katolicismen, hvis man skal følge H.N. Clausens opfattelse.

Med denne beskrivelse af henholdsvis katolicismens og protestantismens væsen og deres principielle teologiske uforenelighed nærmer H.N. Clausen sig en udbredt opfattelse inden for moderne protestantisk teologi, sådan som én af denne teologis grundlæggere, Friedrich Schleiermacher, formulerede det i 1830 i forbindelse med forberedelsen af 2. udgaven af »Der Christliche Glaube«: 
Sofern die Reformation nicht nur Reinigung und Rückkehr von eingeschlichenen Missbräuchen war, sondern eine eigentümliche Gestaltung der christlichen Gemeinschaft aus ihr hervorgegangen ist, kann man den Gegensatz zwischen Protestantismus und Katholizismus vorläufig so fassen, dass ersterer das Verhältnis des Einzelnen zur Kirche abhängig macht von seinem Verhältnis zu Christo, der letztere aber umgekehrt das Verhältnis des Einzelnen zu Christo abhängig von seinem Verhältnis zur Kirche. ${ }^{11}$

Schleiermacher, H.N. Clausen og for den sags skyld også kardinal Ratzinger er enige om, at forskellen mellem katolicisme og protestantisme kan formuleres som en principiel teologisk uenighed om, hvordan man forstår forholdet mellem Kristus og kirken samt de konsekvenser, det har for ekklesiologien. H.N. Clausen placerer sig med sin opfattelse af kirken som et bekendelsesløst religionsvæsen uden historisk eller empirisk virkelighed inden for den del af en protestantisk hovedstrøm, der bygger på den grundantagelse, at Luthers afgørende betydning for forholdet mellem spiritualitet og politik, tro og samfund, individ og fællesskab var, at han adskilte dem. Protestantismens første og vigtigste princip bliver således, at Gud kun findes i hjertets ensomhed og med tankens klarhed. Individualitet og to-rumstænkning er dermed blevet protestantismens egne børn. ${ }^{12}$

Da Grundtvig på den kristne kirkes vegne forkætrer H.N. Clausen, er det et opgør med denne udbredte opfattelse af protestantisk modernitet. Grundtvigs anliggende i »Kirkens Gienmaele" er at vise, hvorfor den fundamentale teologiske adskillelse mellem protestantisme og katolicisme ikke lader sig opretholde. Eller sagt på en anden måde: Grundtvig vil vise, at man ender i kætteriet, når man mister sansen for den reelt eksisterende historiske kirke som bærer af Guds nådemidler i verden. Konflikten mellem H.N. Clausen og Grundtvig bliver dermed en dansk udgave af en klassisk konflikt mellem katolicisme og protestantisme om forholdet mellem retfærdiggørelse og kirke, hvor Grundtvig afviser at følge den moderne protestantiske kontroversteologis synspunkt, men søger at formulere det, vi her vil kalde en katolsk-luthersk opfattelse.

Grundtvig sammenligner i forordet til »Kirkens Gienmaele« sig selv med Irenæus og dennes forsvar for kirken. Det er den samme 
kirke, de forsvarer mod kætterier, og Grundtvig anslår allerede på titelbladet med en henvisning til Confessio Augustana art. VIIs udsagn "Una sancta ecclesia perpetuo mansura sit" sit ekklesiologiske grundtema: at bevidne kirkens enhed gennem tiderne som et historisk faktum og en teologisk norm. I forordet til »Kirkens Gienmale « fremhæver Grundtvig således flere gange, at den kristelige kirke ikke er en tom eller omtvistelig indbildning, men »det er en aabenbar Kiends-Gierning, et velbekiendt historisk Factum, som al Verdens Protest ei kan rokke et Haarsbredd, end sige tilintetgiøre...« (s. IV). Grundtvig kan derfor kalde den kristne kirke for »en mageløs Kiendsgerning « (s. V). Anklagen mod Clausen bliver da, at han gør kirken »ubekiendt og ukiendelig« (s. VIII), eller som Grundtvig kan sammenfatte anklagen: Clausen gør kirken til et »Luft-Castel« (s. 2). Grundtvig giver flere eksempler på, hvordan Clausen bygger sit luftkastel, og han afviser bl.a., at de reformatoriske menigheder med deres protest mod pavedømmets misbrug skulle have løsrevet »sig fra den eneste sande, almindelig (catholsk) christelige Kirke, som ene hviler paa det historiske Fundament...." (s. 3). I stedet henviser Grundtvig til »Erfaringens historiske Vidnesbyrd « som bevis for, at de protestantiske kirker har bevidnet den apostolske tro og bekendelse gennem tiderne. Kirken er således for Grundtvig ikke et "Samfund til at fremme almindelig Religieusitet (s. 9), men »den Christelige Kirke (Ecclesia Christiana) er et Troes-Samfund, med en TroesBekiendelse, som den forelægger alle dem, der vil indlemmes i den, indlemmer dem kun ved Daaben og Nadveren i sig, naar de tilegne sig Bekiendelsen, og anseer dem som Frafaldne, naar de siden vrage Troen eller vægre sig ved Bekiendelsen, erklærer dem for falske Christne ग: Kiættere, hvis de, vitterlig afvigende fra Bekiendelsen, haardnakket paastaae Ret til ligefuldt at hedde Christne« (s. 9).

Det er Grundtvigs påstand, at den sande kristne kirke fra sin begyndelse og frem til i dag kan kendes på den apostolske trosbekendelse som vilkår for indlemmelse $\mathrm{i}$ kirken og på dåben og nadveren som den saliggørende kraft. Det er denne kirke, som ifølge Grundtvig findes over hele jorden og i mange forskellige skikkelser, hvor troen forkyndes på »Jesum Christum, den Korsfæstede, igien Opstandne, som den sikkre, den eneste Saligheds Vei for Syndere, som en Vei, der, giennem Daaben og Nadveren, fører til Guds Rige og de Levendes Land « (s. 26). Den apostolske trosbekendelse, dåb og nadver er således for Grundtvig det grundkristelige, der skal forene alle kristne 
som Kirke på trods af teologiske læreforskelle og dermed ligne de første kristne, som også holdt sammen på grund af og under kristendomsforfølgelserne (s. 28).

Bevidnelsen af det grundkristelige som enhedens og fællesskabets fundament i Kirken giver Grundtvig en frihed i forhold til bedømmelsen af Luthers teologi og den lutherske konfessions autoritet. Grundtvig kan på den ene side rose Luther (og Melanchton) for i Confessio Augustana at have bundet de lutherske lærere til den apostolske trosbekendelse (Confessio Augustana III) og til den eneste sande, historisk-kristelige, uforanderlige, katolske kirke (Confessio Augustana VII og XXI) og på den anden side kritisere ham for at have grundlagt et nyt eksegetisk pavedømme, der kan misbruges til at nedrive den historisk-kristelige kirke til fordel for Clausens luftkastel, hvis man ikke agter på den afgrundsdybe forskel i omgangen med skriften, der hersker mellem Luther og Clausen (s. 31f.). Grundtvig fastholder over for Clausen Confessio Augustana og Luthers lille katekismus som den danske kirkes bekendelsesskrifter, dels på grund af deres bevidnelse af troens indhold, dels fordi en statsmagt må vide, hvilken lære, præsterne, som den lønner, vedkender sig.

Med »Kirkens Gienmale« har Grundtvig anslået en række temaer og teologiske argumentationsrækker, som han vender tilbage til og applicerer på nye situationer og spørgsmål, som stilles i perioden efter 1825. På en række af disse områder er der tale om en vis form for kontinuitet, således som det $\mathrm{fx}$ fremgår af Grundtvigs genudgivelse af skriftet »Skal den Lutherske Reformation virkelig fortsattes? « i 1863, der oprindeligt blev trykt i Lindbergs »Maanedsskrift for Christendom og Historie" i 1831. Grundtvig fremhæver i forordet til 1863-udgaven, at der var adskilligt, han gerne ville have ændret, herunder især betragtningerne vedrørende bispeembedet, men at det grundlæggende $\varnothing$ nske om at højne Biblens og lutherdommens anseelse fortsat er intakt ${ }^{13}$. Ligeledes henviser han til Kirkens Gienmoele som det skrift, hvor han har formuleret sin afgørende indsigt om kirken: at »den Christne Kirke er et fra alle Andre kiendelig adskildt Troes-Samfund ${ }^{14}$. Grundtvig betoner atter den apostolske trosbekendelse som det punkt, hvor kirken adskiller sig fra alle andre samfund. Trosbekendelsen er således både vilkår for optagelse $\mathrm{i}$ samfundet og det væsentlige foreningspunkt i kirken. Derfor eksisterer der for Grundtvig en samhørighed mellem kirker og en indre sammenhæng ned igennem kirkehistorien og tilbage til apostolsk tid 
i den fælles bekendelse af den apostolske tro. I forhold til »Kirkens Gienmale " kan Grundtvig derfor i »Skal den Lutherske Reformation virkelig fortsattes? « betone, at den lutherske reformation ikke har gjort nogen væsentlig forandring i kirken, men blot ført kirken tilbage til den ægte, oprindelige kristne kirke. Det lutherske ved den lutherske kirke består således for Grundtvig $\mathrm{i}$, at den er det kirkesamfund, der har fulgt grundsætningen om, at hvad der væsentlig udgør det kristne trossamfund, skal under alle omskiftelser bevares uforan$\operatorname{dret}^{15}$. Den lutherske reformation er for Grundtvig en tilbagevenden til det grundkristelige i kirken og reformationen skal som sådan fortsættes. Grundtvig formulerer sit syn på Luther og den lutherske reformations nødvendighed således:

..i mine Øjne er det soleklart, at Morten Luther var en mageløs Kirke-Reformator af Guds Naade, fordi han fandt, at hvad den Christne Kirke fattedes, var ingenlunde en ny Tro, eller Nyt af noget Slags, men Liv og Lys i den ældgamle Tro og Indretning, og fordi han fandtes ligesaa dygtig som villig til at afhjelpe Savnet. Herren har nemlig bygget sin Kirke ikke af døde, men af levende Stene, og lider ingen Tilbygninger, som altid blive Røver-Kuler: men desuagtet var dog hans Kirke i Tidens Løb blevet hardtad steendød, da den Gnist af Liv, der end var tilbage, misbrugdes til at giøre Røgelse paa Afguds-Altre. ${ }^{16}$

Denne reformation skal ifølge Grundtvig fortsættes, fordi det kristelige liv er ved at udd $\varnothing$, og selv om Grundtvig ikke ser sig selv som en ny Luther, så kan han alligevel forestille sig, hvordan Luther vil se på hans værk, når de engang mødes i Himmerig: »og jeg veed, at naar vi mødes i Himmerig, vil han sige: det var i Grunden ikke at takke dig for, thi det var kun din Skyldighed, men du skal dog have Tak derfor af Morten Luthers Aand! « ${ }^{17}$

Den lutherske kirke er således ikke en ny kirke, men det nye er, at kampen for den reformatoriske fornyelse ikke længere skal føres mod Romerkirken og pavedømmet, men det nye pavedømme: ærkeprotestanterne, der bygger kirker som luftkasteller ud fra den »saakaldte philosophiske Theologi, der hverken er mindre selvmodsigende eller mere christelig, fordi den udleder sin Myndighed ikke fra Christus ved Guds høire Haand, men fra en vis luftig, mystisk, upersonlig Person ved Navn Fornuften.. ${ }^{18}$ 
Dermed er vi atter tilbage ved Grundtvigs opgør med H.N. Clausen i "Kirkens Gienmale" som en grundlæggende teologisk diskussion om, hvad og hvem der skal være autoritet i den kristne kirke. For Grundtvig er fornuften en latterlig autoritet, som kun kan herske ved at tvinge til blind underkastelse eller overtroisk ærbødighed. Grundtvig indvender mod rationalismen, at den ikke anerkender, at der er en evig sandhed, som aldrig kan blive løgn. Den evige sandhed for Grundtvig er Jesus Kristus som sand Gud, og dermed er vi i lighed med "Kirkens Gienmaele" henvist til at finde den afgørende forskel mellem Grundtvig og ærkeprotestanterne, in casu: H.N. Clausen, i kristologien og den vægt, denne tillægges for den kristne tro, således som den bekendes i den apostolske trosbekendelse. Den kristne tro står og falder for Grundtvig med, hvorvidt der var et eneste falsk eller løgnagtigt ord i den trosbekendelse, som er gjort til vilkår for optagelsen i den kristne kirke.

Grundtvig er her på vej til at gøre sammenhængen mellem bekendelse af den apostolske tro, dåb og kirke til de afgørende omdrejningspunkter i det teologiske opg $\varnothing \mathrm{r}$ mod rationalismen. Slagmarken er i både »Kirkens Gienmale" og »Skal den Lutherske Reformation virkelig fortsattes? « ekklesiologien, hvor den historiske dimension ved den kristne kirke gennem tiderne betones som et udtryk for både troens apostolske indhold og autoritet samt kirkens apostolicitet i tid og rum. Til troens inkarnatoriske natur svarer således for Grundtvig kirkens historiske kontinuitet. Kirken er i den forstand Guds rige på jorden, midt i menneskers historie, fordi kirken gennem sin apostolske trosbekendelse bevidner troens indhold og gennem dåb og nadver rækker mennesker sakramenterne som den saliggørende kraft og pantet på Guds rige midt i deres historie.

Den kristne tro kan således ikke forandres eller modsiges, fordi den har sin forudsætning hos Gud og ikke hos mennesker, og Grundtvig kan derfor tale om den kristne kirkes umistelige frihed som det afgørende princip for forholdet mellem stat og kirke og for forholdet mellem kirker. Reformationen er i Grundtvigs kirkehistoriske forfatterskab en afgørende begivenhed, fordi den er med til at give kirken sin frihed tilbage og gøre op med det princip, hvor der er sammenfald mellem statskirke og kirkestat. Dette princip ser Grundtvig etableret i det han kalder »det hedensk-romerske Princip, at giøre Kirken til en blot Stats-Indretning « ${ }^{19}$. Reformationen sætter således en proces igang, som fører kirken til en stadig større grad af frihed 
over for staten. Det første skridt er for Grundtvig dannelsen af »endeel protestantiske National-Kirker $\aleph^{20}$. Han beklager, at valget mellem de religiøse samfund, der opstod i reformationstiden, ikke blev ladt frit, og at man således ikke gav andre den religionsfrihed, man selv gjorde brug af.

Frihed $\mathrm{i}$ trosanliggender svarer for Grundtvig til frihed $\mathrm{i}$ valg af ikke blot kirkeligt tilhørsforhold, men til religionsfrihed (forstået som konfessionel frihed) som sådan. Han stræber mod den sunde konkurrence og frihed mellem kirkesamfundene og betragter her datidens udvikling i England som løfterig, fordi der er det blevet en fri sag, hvorvidt man vil være lutheraner, katolik, anglikaner, socinianer eller kvæker. Det afgørende er teologisk set, at Grundtvig begrunder sine synspunkter angående konfessionel frihed i nationalkirken med en henvisning til troens indhold. Det er »til Ære for Troens Kraft «, at kirkeordningen skal være en fri sag, for intet menneskeligt skal kunne anmasse sig herredømme over troen ${ }^{21}$.

En tilsvarende udvikling bør efter Grundtvigs mening også foregå i Danmark, så der opstår dét, han kalder et venligt forbund mellem stat og kirke. Til dette venlige forbund svarer begrebet Nationalkirke, der således i Grundtvigs vokabular antyder en kvalitativ anderledes kirkeindretning end den, der ligger i begrebet Statskirke. I den danske nationalkirke er der ifølge Grundtvig en grunduenighed mellem modstridende og med hinanden uforenelige konfessionelle retninger. Derfor er opgaven ikke at vedligeholde en kirkelig fred og enighed, men at finde en måde, hvorpå denne strid kan føres. Grundtvigs konklusion er klar. Han hævder, at en kirkelig skilsmisse er uundgåelig, så kampen om den sande og rette tro kan føres i fri konkurrence uden statens formynderiske indblanding. Grundtvig er ikke i tvivl om, at hans trosforståelse er den sande, og betydningen af at nære den blandt ligesindede og give den videre til sine børn er så stor for ham, at han betragter en forandring af kirkeindretningen som en mindre vigtig sag $^{22}$. Grundtvig argumenterer derfor for en ny ordning af forholdet mellem stat og kirke, der må begynde med en skilsmisse mellem de to på en sådan måde, at de kan leve ordentlig sammen på ny. Der ville ikke være tale om at opløse nationalkirken, sådan som man har gjort det i Nordamerika, hvor religion er blevet en privatsag. I stedet forestiller Grundtvig sig, at hvor der »blev givet en udstrakt Religions-Frihed, medens det dog vedblev at være den gamle luthersk-reformerede Christelige Kirke, hvortil Mængden af Folket hør- 
de, og hvori derfor Regieringen udnævnede Lærere, og ordnede Forfatningen, der var den Lutherske Reformation i Kirkens Forhold til Staten virkelig blevet fortsat, idet den dunkle og skiæve Idee om en christelig National-Kirke havde klaret og rettet sig, til Begrebet om den Christne Kirke i et frit Forbund med Staten, som hjemlede Statens Overhoved al den Kirke-Magt, Samme med Føie kan ønske sig, uden at der dog skedte noget Skaar i Samvittigheds-Friheden, som er en umistelig Menneske-Ret! ${ }^{23}$.

Der er altså fortsat tale om elementer af statsindretning i Grundtvigs beskrivelse af kirkens indretning, men han forudser, at de sidste rester kan forsvinde, hvis staten opkaster sig til herre over troen i statskirken, eller hvor mængden af folket vender sig bort fra kristendommen.

Som det er fremgået, er det en perspektivforkortning at tillægge Grundtvig det synspunkt, at spørgsmål vedrørende kirkeordning udelukkende kan besvares pragmatisk som et lovgivningspolitisk anliggende. Grundtvigs kirkesyn er båret af et historisk og et teologisk princip, der munder ud i en besindelse på troens frihed, sådan som dette går tilbage til den apostolske bekendelse som det afgørende princip for indretningen af nationalkirken. I Danmark er denne nationalkirke konfessionelt bestemt som en luthersk kirke, så længe folket vil det, og denne lutherske kirke er teologisk at forstå som en bevidnelse af den oprindelige apostolske tro i den form, som nu historien har udformet den her hos os. Det nationale er således underlagt det historiske længdeperspektiv og er derfor hos Grundtvig ikke det første udgangspunkt for en besindelse på kirkens teologiske indhold. Det første udgangspunkt er troen på den treenige Gud, og det nationale hører således i Grundtvigs ekklesiologi hjemme i det relative eller i det næstsidste.

På samme måde kan det konstateres, at Grundtvig teologisk set først taler om den kristne kirke, før han taler om den danske nationalkirke. Det kommer tydeligst frem i hans behandling af forskellen mellem den apostolske trosbekendelse og Biblen som norm i kirken. Her udnytter Grundtvig den nære sammenhæng mellem dåb og apostolsk trosbekendelse, hvor bekendelsen som trosord får karakter af dåbens indstiftelsesberetning. Dermed formulerer Grundtvig en parallelstruktur mellem indstiftelsesberetning og sakramentsfejring, som også kendes fra nadveren. Den danske kirke er for Grundtvig ét med »den Grund-christelige«, sådan som det også fremgår »i Bibelen, 
hvad der dog staar, at hos de Christne skal der ligesaavel være samme Tro og Daab, som der skal være een og samme Aand og Herre $\ll^{24}$. Grundtvig henviser her øjensynligt til Ef. 4,4-6, sådan som stedet også indgår i Confessio Augustana VIIs skrifthenvisning som udtryk for, hvad der er nødvendigt til kirkens enhed. Dåben er således ifølge Grundtvig noget, alle kristne skal have tilfælles, og den er den fælles apostolske trosbekendelse, der gør den kristne kirke kendelig for venner og fjender. Den sande kirke kan altså ses, når den fejrer dåb i overensstemmelse med den apostolske tradition, sådan som denne er bevidnet gennem kirkens historie. Om dåb og trosbekendelse kan man ifølge Grundtvig ikke diskutere, og de kan heller ikke glemmes eller lægges på hylden. Det kan man derimod med enhver bog - og dermed også med Bibelbogen. Den deler i det stykke skæbne med alle andre bøger og kan ifølge Grundtvig ikke være autoriteten i kirken. Det betyder ikke, at Grundtvig ikke kan bruge Biblen. Han har været meget bibelkyndig, og han benytter $\mathrm{i}$ sine skrifter gerne henvisninger til Skriften - enten direkte eller indirekte. Men skrifthenvisningerne tjener som i dette tilfælde til at underbygge den apostolske tro og sakramenternes autoritet i kirken som Guds Ord til syndernes forladelse og det evige liv.

Dåben som det enhedsskabende princip i kirken understreges yderligere af Grundtvigs betoning af, at »Hvem der virkelig har Daab tilfælles med os, maae vi nemlig ikke udelukke af det Christne KirkeSamfund, med mindre vi kan bevise, han har brudt sin Daabs-Pagt, og angrer det ikke ${ }^{25}$. Konsekvensen er blandt andet, at Confessio Augustana ikke kan have almengyldighed som læreforskrift eller trosbekendelse i den kristne kirke, fordi man ifølge Grundtvig ikke kan fordre, at de, der levede før 1530, kunne følge bekendelsens ordlyd. Skal man tolke Grundtvigs position ud fra katagorierne norma normans og norma normata er norma normans ikke skriften, men Guds Ord i den apostolske trosbekendelse, dåb og nadver, mens norma normata både er skriften, kirkehistorien og bekendelsesdannelser som fx Confessio Augustana, fordi disse på forskellige måder udfolder, hvad der hører til kirkens tradition. Kirkens enhed er for Grundtvig et praktisk gudstjenestefællesskab, hvor enheden grundlægges og bevidnes offentligt i den apostolske trosbekendelse og sakramentsfejringen. Dermed har Grundtvig i skriftet »Skal den Lutherske Reformation virkelig fortsattes? " leveret sin egen tolkning af Confessio Augustana VII som en artikel om kirkens enhed, der indeholder, hvad 
vi kan kalde en økumenisk ekklesiologi. Den kan han samtidig anvende kritisk over for de eksisterende kirkesamfund: den pavelige vinkelkirke, der er som det stillestående vand, den bevagelige zwingelske, der er som bølgerne for alle vinde, eller sin egen danske nationalkirke, der endnu ikke har fattet betydningen af den apostolske trosbekendelse og sakramentsfejringen som Ordet, hvoraf mennesket lever, og som udgår fra Guds mund.

Grundtvig fremsætter i mange forskellige sammenhænge en teologisk baseret kritik af de bestående forhold i både stat og kirke. Det gælder ikke mindst kravet om mere frihed i kirken, sådan som det kommer klart til udtryk i hans tale til folkerådet i Roskilde om dansk kirkefrihed ${ }^{26}$. Her anfører han, at gejstlighedens protest mod folkets og især imod bøndernes samvittighedsfrihed er en papistisk protest og som sådan ukristelig, udansk og uprotestantisk ${ }^{27}$. Spørgsmålet om samvittighedsfrihed hører for Grundtvig nemlig ikke ind under gejstlighedens forum, men under det borgerlige selskabs forhold. I det stykke anvender Grundtvig en tolkning af Confessio Augustana angiveligt art. XXVIII - der erklærer, at biskoppernes tvangsret, magt og myndighed har de fra den verdslige øvrighed og ikke i kraft af deres embede som lærere i Kristi kirke. Grundtvig kan derfor anføre en vigtig og principiel skelnen mellem protestanter og papister, der går som en rød tråd igennem hans forfatterskab:

\begin{abstract}
Efter Confessionen er nemlig Protestanter og Papister aldeles enige saavel om den almindelige christne Tro, som om at der er en Lærestand, indstiftet af vor Herre Christus selv, men det er egentlig det store Tvistens Æble imellem dem, at Papisterne paastaae, den verdslige Øvrighed skal lade Geistligheden herske over deres Undersaatters Samvittighed og skal straffe hvem der viser sig gienstridig, hvorimod Protestanterne staae hardt paa, at Christi Rige er slet ikke af denne Verden, saa hans Embedsmænd har ikke mindste Ret til at kræve anden Lydighed end den, Man godvillig viser dem for Christi Skyld « ${ }^{28}$.
\end{abstract}

Bag Grundtvigs synspunkt ligger en skelnen, som han henter hos Martin Luther, mellem den kristne kirke som ét af staten uafhængigt begreb og statskirken med sin statsgejstlighed, der er en skabning af den danske regering, in casu: kongen. Grundtvig har stor tillid til, at regeringen med sin uindskrænkede ret over statskirken, vil »ophæve 
eller omdanne vor Stats-Kirke, og giøre den enten saa tvungen eller saa fri, saa herskende eller saa tjenende, som den behager, og vil da sikkert nu giøre den saa folkelig som mueligt, da den ene er til for Folkets, ligesom Sabbaten for Menneskets Skyld, og da den nu, deels forhadt og deels forladt af Folket, i sin gamle Skikkelse kun er til Byrde og, hvor Sogne-Prasterne udøve deres Tvangs-Ret, til utaalelig Plage ${ }^{29}$.

Grundtvig anvender i sin tale en bemærkelsesværdig dobbelt strategi. Først appellerer han til regeringen om at erkende sin magt over statskirken, hvormed han af teologiske grunde får placeret gejstligheden udenfor den verdslige magt i statskirken. Dernæst udfordrer han regeringen til at benytte sin egenrådige magt til at give statskirken en ny folkelig skikkelse, der skal komme til udtryk i en strukturel gennemført samvittighedsfrihed $\mathrm{i}$ form af sognebåndets løsning og præstefrihed. Længere går Grundtvigs ønsker ikke på dette tidspunkt i slutningen af 1830erne, men i samtiden er de teologisk og politisk meget radikale. Der er fra Grundtvigs side tale om et såkaldt fredsforslag, som han selv betegner som »en lille Forandring«, hvorved enhver kan beholde $\sin$ tro $^{30}$. Men forandringen er dog så stor, at biskop Mynster gik imod forslaget, og Grundtvig må bruge megen energi på at tilbagevise påstanden om, at hans forslag om præstefrihed og sognebåndets løsning vil ødelægge statskirken i form af »en Hærskares Mangfoldighed af kirkeløse Mennesker, af daarlige Confirmander og gudelige Forsamlinger « ${ }^{31}$. Tværtimod vil mere frihed i kirken fremme de kirkeløses tilhørsforhold til en bestemt præst, konfirmanderne vil blive bedre, fordi de vil møde interesserede og dygtige præster, og de gudelige forsamlinger vil miste deres tiltrækningskraft, fordi de er drevet frem som en protest mod statskirkens tvang. Protesten vil således ifølge Grundtvig blive genstandsløs, når statskirken indrettes ud fra princippet om trosfrihed.

Spørgsmålet om forholdet mellem »Stats-Kirken« og Kristi »hellige, almindelige Kirke« er afgørende for Grundtvig i denne periode fra 1825 og frem til $1830^{\prime}$ ernes afslutning. Således tager han anledning af et brev fra den engelske præst Wade, der havde været ansat i Helsingør, til den 12. juni 1839 at sende Wade et åbent brev, hvor han bl.a. understreger forskellen mellem statskirken i England og Danmark ${ }^{32}$. Grundtvig betoner atter, at hans opgør med H.N. Clausen og kravet om samvittighedsfrihed som konsekvens måtte blive: »Udtrædelse af Stats-Kirken vilde være den eneste Maade, hvor- 
paa Lutheranerne kunde nære sig i Landet og forplante deres $\mathrm{Tro}^{33}$.« Grundtvig henviser til sine egne erfaringer som udtryk for begrænsninger i den frihed, han har ønsket sig. I 1831 fik han således afslag på en ansøgning om et præsteembede, ligeledes betoner Grundtvig, at han i 1832 kun fik lov til at holde offentlig gudstjeneste hver søndag efter statskirkens liturgi med fri tilhørere. Med det åbne Vennebrev, der indeholder tiltrædelsesprædikenen fra Vartov i 1839, markerer Grundtvig, at friheden er blevet større for ham i Statskirken. Men han afviser at lade Statskirken definere, hvad der er sand og ret kirke, hvorved han selv skulle blive holdt udenfor. Det afgørende ekklesiologiske synspunkt i Vennebrevet er således Grundtvigs betoning af: »jeg kommer ikke fra nogen Sekt i aandelig og christelig Forstand; thi jeg kommer fra den hellige, »almindelige Kirke«, som varer alle Dage til Verdens Ende, med een Herre, »een Tro, een Daab«, een Gud og Alles Fader « ${ }^{34}$.

Atter ser vi, at Grundtvig definerer sin kirkeforståelse ud fra et bibelsk, reformatorisk og historisk synspunkt, hvor den eneste reference til den danske sammenhæng er en kritik af de statskirkelige forhold. Nationalitet og folkelighed bringes ikke $i$ anvendelse til at beskrive idealet af den kirke, som Grundtvig forstår sig selv som præst i.

Det er interessant, at Grundtvig betoner sammenhængen mellem den ene historiske kirkes virkelighed og troen, dåben og den treenige Gud, som konstituerer denne ene kirke. Dermed lægger Grundtvig sig i forlængelse af Martin Luthers tale om sammenhængen mellem den synlige og den skjulte kirke. De anvender begge talen om kendetegn/ Kiendemærker til at betone, at de tegn, der kendetegner kirken som en historisk virkelighed, er de samme tegn, som konstituerer denne kirke. For både Luther og Grundtvig er det vigtigt at tale om kirken som et kristent helligt folk, der lever af Kristi sakramentale nærvær. Luther kan udtrykke dette forhold på den måde, at Gud i evangeliet handler med os på to måder: ydre og indre. I det ydre handler Gud med os gennem evangeliets talte ord og gennem de legemlige tegn som dåb og nadver. I det indre handler Gud med os gennem Helligånden og troen sammen med andre gaver. Luther betoner, at rækkefølgen mellem det ydre og det indre er vigtig. Det ydre kommer altid før det indre. Troen kommer af det evangelium og de sakramenter, Gud selv har indstiftet ${ }^{35}$. 
Luther og Grundtvig er fælles om at betone vigtigheden af kirkens historiske karakter, fordi kirken er det sted, hvori evangeliet og sakramenterne rækkes til mennesker, så troen kan bo i deres hjerter. If. David Yeago er det den samme tanke om, at det ydre går forud for det indre, dvs. at nåden er uadskillelig fra og afhængig af det sakramentale nærvær, der ligger bag Luthers syn på den konkrete gudstjenestefejrende menighed som en identifikation af kirken. Netop i gudstjenesten er den indre enhed i tro og Helligånd konstitueret i og ved en offentlig sakramental praksis.

Her begynder en luthersk og grundtvigsk tale om kirkens synlige enhed. En ny besindelse på Grundtvigs forståelse af den gudstjenestefejrende menighed som udtryk for den synlige kirke vil samtidig frigøre teologien til at yde en konstruktiv tolkning af Grundtvigs bidrag til den aktuelle økumeniske læresamtale om ekklesiologi, embedsteologi, forholdet mellem Skrift og tradition, og sammenhængen mellem nationalitet, konfessionalitet og universalitet.

\section{Noter}

1 A.M. Allchin, The Kingdom of Love and Knowledge, London 1983. A.M. Allchin and others (ed.), Heritage and Prophecy. Grundtvig and the English-Speaking World, Aarhus 1993. Lilian Zøllner (red.), Rodfostet Universalisme. N.F.S. Grundtvigs poesi, menneskesyn, kultursyn, skolesyn, Vejle 1996. A.M. Allchin, N.F.S. Grundtvig. An Introduction to his Life and Work, Aarhus 1997.

2 Se f.eks. Peder Nørgaard-Højen, Der Beitrag Grundtvigs zur Kontroverse über die Beziehung von Schrift, Tradition und Kirche, Festschrift für Theodor Jørgensen, Frankfurt a/M 1996, s. $31 \mathrm{ff}$.

3 Forord ved Hans Kring i forordet til Kirkens Gjenmale ved Nik. Fred. Sev. Grundtvig 1825. Paany udgivet af Kirkeligt Samfund Kbh. 1925.

Også Anders Nørgaard understreger i sit forord til fjerde udgave af N.F.S. Grundtvigs Den Christelige Børnelardom i 1941 Grundtvigs betydning således: »denne danske Mand faar nu i Nфdens bitre Time, to Menneskealdre efter, han lukkede sine Øjne, sit Navn paa alles Laber«.

4 Ove Korsgaard, Kampen om lyset. Dansk voksenoplysning gennem 500 år, København 1997, s. $185 f$ f.

5 Ibid. s. 189. 
6 Ibid. S. 182. Ove Korsgaard forholder sig på dette sted kritisk til K.E. Bugges disputats Skolen for Livet fra 1965, som han kritiserer for at fremstille Grundtvigs pædagogiske tanker som afsluttede i 1847.

7 Især A.M. Allchin har i sin bog N.F.S. Grundtvig. An Introduction to his Life and Work, Aarhus 1997, fremhævet Grundtvigs slægtsskab med den samtidige Oxford-bevægelse, når det gjaldt om at betone kirkens historiske og universelle identitet som et tegn på Gudsrigets tilstedeværelse i verdens tid og rum (s. 105ff.).

8 H.N. Clausen, Catholicismens og Protestantismens Kirkeforfatning, Lare og Ritus, Kjøbenhavn 1825, s. 68-72.

9 Ibid. s. 69-70.

10 Ibid. s. 71.

1 Friedrich Schleiermacher, Der Christliche Glaube, Siebente Auflage, Zweiter Band, Hrsg. Martin Redeker, Berlin 1960, s. 507.

Schleiermacher opstiller dermed et problem, der har fulgt teologien lige siden og i øvrigt i dag deles af fx Kardinal Ratzinger, som har sammenfattet Luthers fundamentale uenighed med katolicismen således:

»..in Luther's view faith is no longer, as it is for Catholics, of its essence a sharing of faith with the entire Church; for him at least the Church can neither assume the guarantee of certainty for one's personal salvation nor decide in a definitively binding manner about the content of faith. For Catholics on the contrary the Church itself is contained in the inmost principle of the act of faith; it is only by sharing in faith with the Church that I have a part in that certainty on which I can base my life « (Joseph Ratzinger, Church, Ecumenism, and Politics, New York 1988, s. 113).

12 Se hertil også David S. Yeago, "'A Christian, Holy People' Martin Luther On Salvation And The Church«, Modern Theology 13:1 January 1997, Oxford 1997, s. 101-120.

13 N.F.S. Grundtvig, Skal den Lutherske Reformation virkelig fortsattes?, Kiøbenhavn 1863, Forord.

14 Ibid. s. 12.

15 Se f.eks. Grundtvigs indledning i Skal den Lutherske Reformation virkelig fortsattes?, s. 11.

16 Ibid. S. 16. 
17 Ibid. S. 79.

18 Ibid. s. 21.

19 Ibid. s. 37.

20 Ibid. s. 40.

21 Ibid. s. 41.

22 Ibid. s. 47.

23 Ibid. S. 51.

24 Ibid. s. 84f.

25 Ibid. s. 103.

26 Tale til Folkeraadet om Dansk Kirkefrihed savnet af Nik. Fred. Sev. Grundtvig, Proest, Kjøbenhavn 1839.

27 Ibid. s. 14.

28 Ibid. s. 15.

29 Ibid. s. 17.

30 Ibid. s. 26-27.

31 Ibid. s. $30 \mathrm{ff}$.

32 Nik. Fred. Sev. Grundtvig, Aabent Vennebrev til en Engelsk Prast, 2. Oplag, Kjøbenhavn 1839.

33 Ibid. s. 10.

34 Ibid. s. 22.

35 D. Martin Luthers Werke, Kritische Gesamtausgabe, 18. Band, Weimar 1908, s. 136. Se også David S. Yeago, "'A Christian, Holy People' Martin Luther On Salvation and the Church«, Modern Theology 13:1 January 1997, s. 101-120. 